(C) 1983. The Genetical Society of Great Britain

\title{
THE ROBERTSONIAN TRANSLOCATION HOUSE-MOUSE POPULATIONS OF NORTH EAST SCOTLAND: A STUDY OF THEIR ORIGIN AND EVOLUTION
}

\author{
H. R. NASH, P. C. BROOKER AND S. J. M. DAVIS \\ Department of Zoology, University College London, Gower Street, \\ London WCIE 6BT, U.K.
}

Received 5.i.83

\begin{abstract}
SUMMARY
The house mice, Mus musculus, of N. E. Scotland and some of the neighbouring Orkney islands carry Robertsonian translocations (centromeric fusions). By comparing the karyotypes, mandible morphology and biochemical variation of samples from four of these populations we suggest that despite chromosomal differences the populations are closely related. Available evidence suggests that the mice may have arrived with the Vikings as early as $600 \mathrm{~A}$.D. and that the chromosomal changes have occurred since then. We found no evidence that the normal, $2 n=40$, mice are, by other measures, different from those with Robertsonian translocations. The evidence suggests that these populations have been isolated for a considerable period of time during which there has been a marked reduction of polymorphism and heterozygosity in the island samples, which we tentatively suggest may explain differences observed in the chromosomal evolution of the four populations.
\end{abstract}

\section{INTRODUCTION}

Free living house mice with centric (Robertsonian) chromosome fusions were first described by Gropp and his co-workers in 1970. Since then a number of such populations have been discovered in different parts of Europe, including Italy, southern Germany, and Scotland (Capanna et al., 1977; Adolph and Klein, 1981, 1982; Brooker, 1982).

Each Swiss and Italian population is characterised by a number of fused chromosomes in a homozygous state, each population being homogenous. In Italy narrow hybrid zones between Robertsonian and normal populations occur, but complete reproductive isolation between two sympatric Robertsonian populations has also been observed (Spirito et al., 1980; Capanna and Corti, 1982). There is evidence from laboratory studies that heterozygotes suffer reduced fertility (Capanna et al., 1977 Cattanach, 1982). In Caithness, north-east Scotland, and in southern Germany the populations are karyotypically heterogeneous; however, the two populations found in the Orkneys with translocations were homozygous and homogenous. One of the translocations, Rb9-12, is common to both islands and to Caithness. Of the other Orkney populations investigated in these earlier studies, all animals had a normal karyotype $(2 n=40)$.

Thorpe and his co-workers (1982) have shown that morphometric distance estimates correlate with reduction in chromosome number in neighbouring north Italian valley populations, and that these mice are more closely related to each other than to nearby normal mice. Davis (1983), calculating morphometric distances for British mice, demonstrated that the 
Caithness and Orkney mice are related to each other and to Hebridean mice, but are quite distinct from all other British mice. They are also the only British mice in which Robertsonian translocations have been found (Brooker, 1982, and in preparation).

Berry and Peters (1977) calculated distance statistics using protein polymorphism data. They did not distinguish Caithness from other British populations. Similarly Britton-Davidian and her co-workers (1980) could not distinguish between Robertsonian and normal mice in Italy.

If Berry (1966) is correct, then the island populations of house mouse around northern Britain are derived from mice introduced from Scandinavia. The earliest links likely to have introduced them were provided by the Viking colonisation around 600 A.D. Some support for this is provided by the finding that the Caithness mice carry the Mor $-1^{\mathrm{c}}$ allele (Berry and Peters, 1977). This allele is not found in other British mice, but is found in Denmark (Hunt and Selander, 1973). Further evidence for a separate origin is perhaps the absence of the common $G p i-1^{\mathrm{b}}$ allele in the Orkney and Caithness mice (the latter are the most polymorphic of British mice).

An interesting parallel is provided by the anthropology of these northern regions. It is known that the majority of human inhabitants of both Caithness and the Orkneys are of Norse descent, and most of the trade was with Scandinavia.

In this paper we compare the Caithness mice with those from three small neighbouring islands, Eday, Westray, and Stronsay, in the Orkney archipelago. Eday and Westray both have mice with Robertsonian translocations, while Stronsay does not. By analysing the karyotype, protein polymorphisms and mandible morphometrics of these populations, some tentative conclusions are drawn about the origins and subsequent evolution of these mice.

\section{MATERIALS AND METHODS}

(i) Animals and sampling

Between 1979 and 1982, mice were either hand caught during the threshing of corn ricks or live trapped (see table 1 for sites). The geography of the three islands and the rest of the Orkney archipelago is shown in fig. 1. The Scottish mainland sample, Caithness, Greenland farm, is sample 6 in Brooker (1982). The animals were transported to the laboratory, caged, and blood was taken from the retro-orbital sinus for karyotype analysis. After karyotyping, the mice were killed and tissues sampled, then stored at $-40^{\circ} \mathrm{C}$ for later electrophoretic analysis. The carcasses were labelled and frozen.

\section{(ii) Karyotyping and morphometrical analysis}

Karyotyping was carried out according to Brooker (1982). Mandible morphometry was carried out as in Davis (1983). Earlier, but undated, material from Westray and Stronsay was also available for morphological analysis and was scored for comparison. 
(iii) Enzyme and protein analysis by starch gel electrophoresis

The loci chosen were those known to be polymorphic in at least one British house mouse population and are therefore a selected sample. They are about one third of the presumptive loci scored in this laboratory. Tissue samples were prepared according to Newton et al., (1982) and electrophoresis according to Berry and Peters (1977). The loci scored, were, in chromosome order: Chromosome -1 , soluble isocitrate dehydrogenase (Idh-1), dipeptidase (Pep-3); Chromosome - 3, carbonic anhydrase (Car-2); Chromosome-4, aconitase $(A c o-1)$, glucose dehydrogenase (Gpd-1); Chromosome-5, mitochondrial malate dehydrogenase (Mor-1); Chromosome-7, phosphoglucoisomerase (Gpi-1), xylose dehydrogenase (Xld-1), protease (Smg-1, Prt-5), mitochondrial malic enzyme (Mod-2), haemoglobin beta chain $(\mathrm{Hbb})$; chromosome-8, glutathione reductase $(\mathrm{Gr}-1)$, carboxyesterase (Es-1, Es-2, Es-5, Es-6, Es-9, Es-11), mitochondrial glutamate oxaloacetic transaminase (Got-2); Chromosome-9, soluble malic enzyme (Mod-1), transferrin (Trf); Chromosome-11, esterase (Es-3); Chromosome-14, esterase (Es-10) (Nichols and Ruddle 1973, 1975; Harris and Hopkinson 1976; Peters and Nash, 1978; Otto and von Deimling, 1981; Nash and von Deimling, 1982; Newton et al., 1982; Nadeau and Eicher, 1982).

\section{Results}

The results of the karyotype analysis are shown in table 1. Robertsonian translocations were found in three of the four populations investigated.

TABLE 1

Distribution of Robertsonian translocations

\begin{tabular}{rrrcr}
\hline \multicolumn{2}{c}{ Sample } & $N$ & $\begin{array}{c}\text { Karyotype } \\
(2 n)\end{array}$ & $\begin{array}{c}\text { Robertsonian } \\
\text { translocations }\end{array}$ \\
\hline \multicolumn{2}{c}{ Caithness (Greenland farm) } & 8 & 34 & $9-12 ; 6-13 ; 4-10$ \\
Eday 1 & 11 & 34 & $9-12 ; 3-14 ; 4-10$ \\
& 2 & 6 & 34 & $9-12 ; 3-14 ; 4-10$ \\
3 & & 5 & 34 & $9-12 ; 3-14 ; 4-10$ \\
4 & & 10 & 34 & $9-12 ; 3-14 ; 4-10$ \\
Westray & 1 (Central) & 14 & 36 & $9-12 ; 6-14$ \\
& 2 (North) & 25 & 36 & $9-12 ; 6-14$ \\
& 3 (South) & 17 & 36 & $9-12 ; 6-14$ \\
Stronsay & & 14 & 40 & \\
\hline
\end{tabular}

The translocation Rb9-12 was homozygous in the Caithness (Greenland farm), Eday and Westray mice. The translocation Rb4-10 was homozygous in the Eday and Caithness samples. The other translocations occurred in only one of the populations. In all cases animals examined were homokaryotypic for this translocation.

Inspection of the morphometric data (table 2) suggests two groups. It would appear that by this measure the Eday and Westray mice are as little differentiated from each other as are the Caithness and Stronsay samples. 


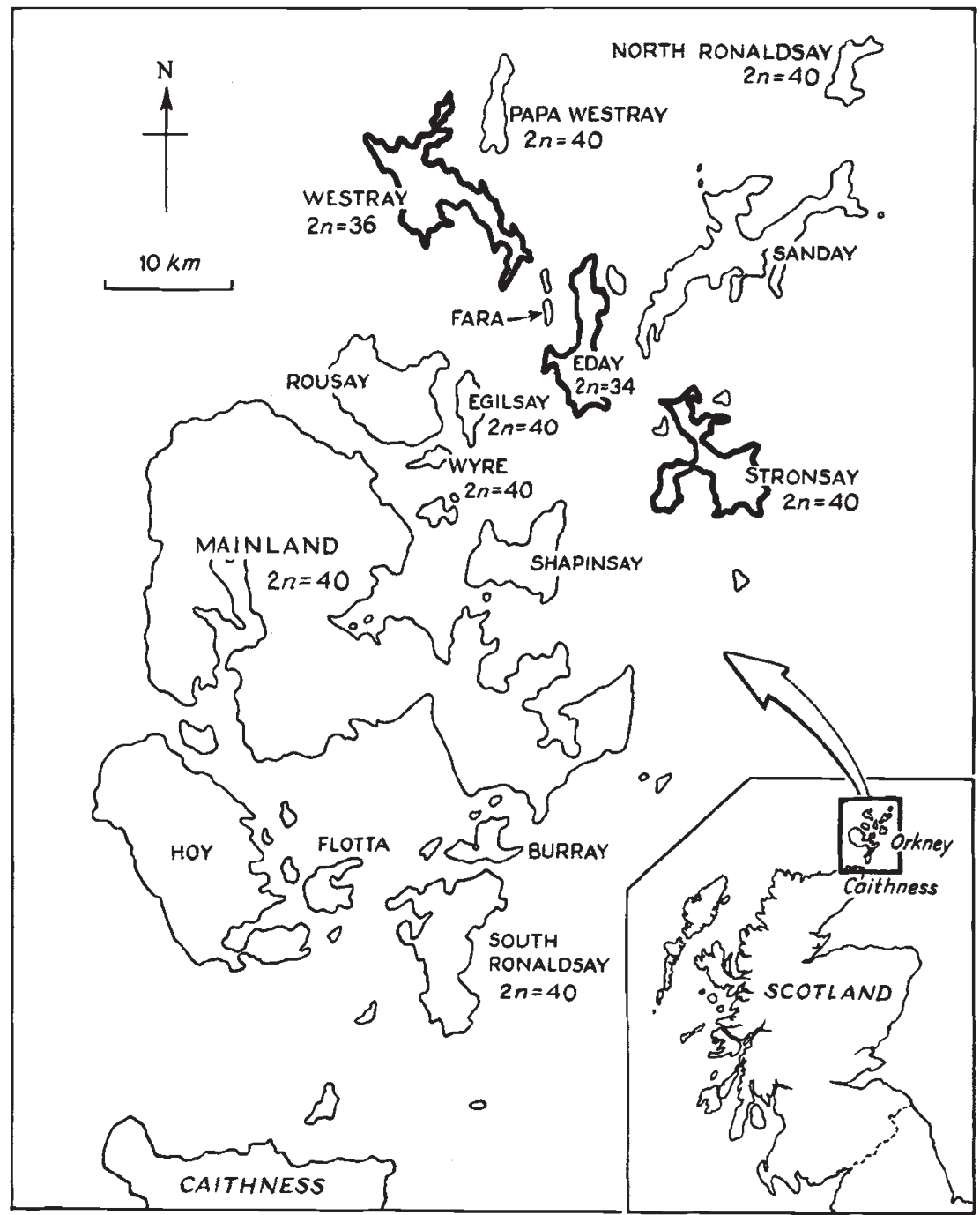

FIG. 1. Map of Orkney Archipelago. The three islands studied are shown in heavy outline and the karyotype, where known, is indicated. Additional data from Adolph and Klein (1981), Brooker (1982).

TABLE 2

Mahalanobis $D$ distances between the populations determined by mandible shape

1) 2) 3)

1) Caithness (Greenland Farm)

2) Eday 3

3) Westray $1 \quad 4.39$

4) Stronsay 2.67 


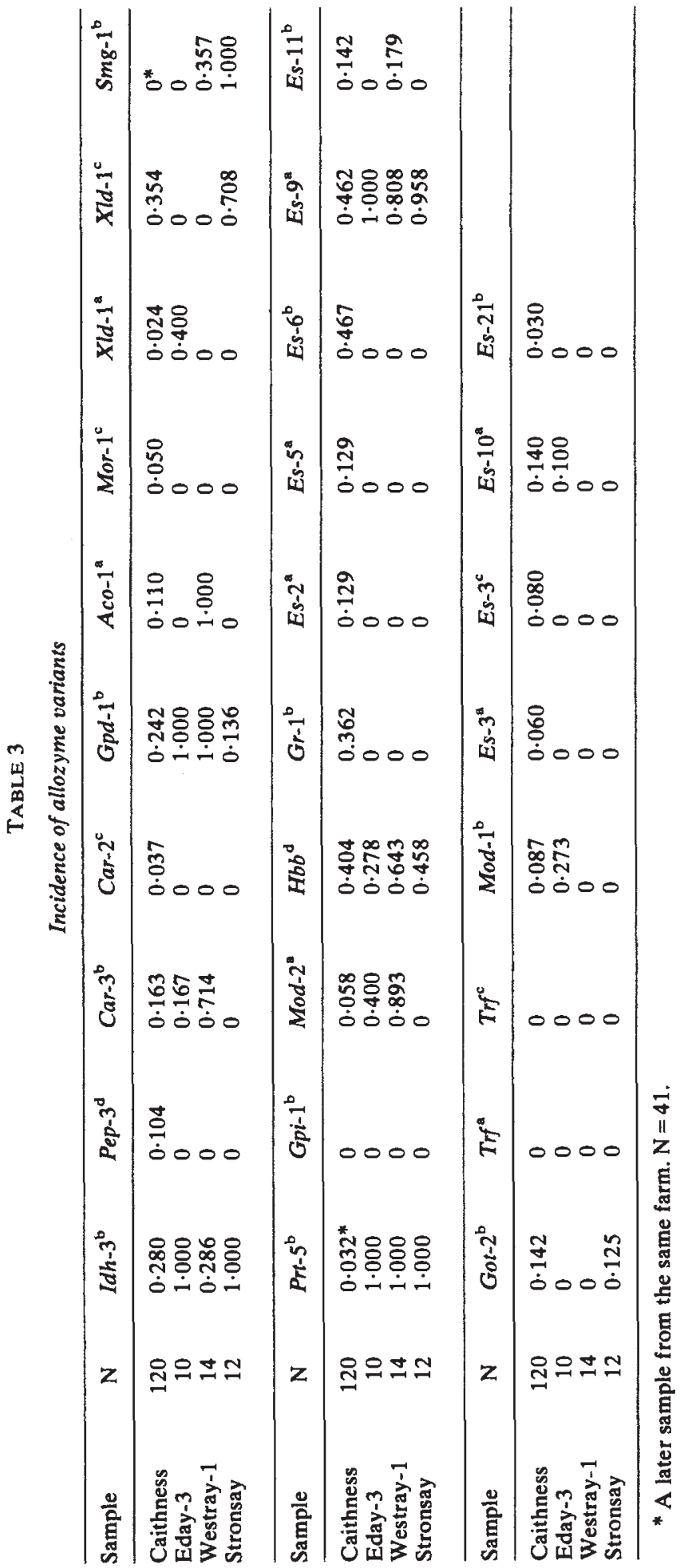


Stronsay and Greenland Farm are separated by a similar distance from the Eday and Westray populations. When the earlier samples from Westray and Stronsay were compared to the present ones the distance for Westray was 2.04 and for Stronsay 2.78 . Unfortunately the date of capture is not known so the period separating the samples cannot be estimated but is probably more than ten years. The distances in the present study between Eday and Westray $(D=2 \cdot 76)$ and Caithness and Stronsay $(D=2 \cdot 67)$ are of the same order as the temporal differentiation in the intra-island comparisons.

The gene frequencies observed for the 24 loci scored by electrophoresis are given in table 3 , the commonest allele in the Greenland population is omitted. The high polymorphism of the Greenland sample is evident, only three of the loci being monomorphic compared to 18, 17, and 19 for Eday, Westray and Stronsay respectively. Despite some small sample sizes, no departures from Hardy-Weinberg expectation were observed, but the reduction of the number of polymorphic loci may be an over estimate for the whole islands. Stronsay and Westray carry the $S m g-1^{b}$ allele absent in both Greenland and Eday, otherwise all the alleles seen on the islands are present in the Greenland sample. The Orkney populations were clearly differentiated from each other by the alleles present for some of the loci, e.g. Car-2, Gpd-1, Aco-1,Smg-1, and Xld-1. Although the Stronsay animals were polymorphic at only five loci, they carry the $G p d-1^{\mathrm{a}}, X l d-1^{\mathrm{c}}$ and Got $-2^{b}$ alleles found in the Caithness mice but not in the Eday and Westray animals.

\section{Discussion}

The four populations of house mice were clearly distinguished by both chromosomal variation and protein polymorphisms. The morphometric data suggest two populations, the first consisting of the two islands, Eday and Westray, containing Robertsonian translocations, and the second of the chromosomally unrelated Caithness and Stronsay mice. The karyotypes clearly distinguish all four populations from each other but also suggest a closer relationship between Caithness and Eday mice which is not supported by the morphometric results. Likewise the close morphometric relationship between Stronsay and Caithness samples is not reflected in the chromosomal observations. These Scottish populations do not therefore follow the pattern shown by the Italian mice investigated by Thorpe et al. (1982).

Biochemically we can view the island populations as subsets of the mainland sample. Only one allele was found on the islands that was not seen on the mainland, Smg-1 ${ }^{\text {b }}$. The later, smaller, sample from which these data were taken showed loss of alleles at other loci (Berry and Nash, unpublished), and we cannot assume that the Greenland farm population is wholly representative of Caithness: the karyotype certainly is not (Brooker, 1982). Both the chromosomal differentiation and protein polymorphism results suggest little or no gene flow between the islands over a considerable time period. Divergence of karyotype would probably intensify the geographic isolation.

The evidence suggests that the mice from all four populations sampled are closely related despite being completely isolated from each other. Divergence between them must have occurred since they colonised the 
area by a combination of founder effects and subsequent evolution. If we date the earliest possible arrival of the mice with that of the Vikings, then the first translocation probably arose since then, presumably $\mathrm{Rb} 9-12$, because the commonest karyotype is $2 n=40$ (Adolph and Klein 1981, Brooker, 1981).

The evidence from Caithness (Brooker, 1982) would suggest that the next translocation was probably Rb6-13, but this is found on neither Eday nor Westray, although Rb4-10, commonly but not always found in Caithness, occurs on Eday. It is possible that Rb4-10 has arisen independently in the two places. This seems unlikely since there is no evidence that particular associations are favoured (Gropp and Winking, 1981) and chance in an evolving population would lead to the expectation of novel translocations such as Rb3-14 and Rb6-14 in Eday and Westray respectively. If this argument is accepted, then mice arrived on Westray before Eday.

Morphometric variation is the result of selection and drift acting on a polygenic system. If the founding animals were as heterozygous for these genes as the biochemical loci observed in the Caithness sample, then there is scope for phenotype divergence upon isolation as heterozygosity is lost.

The question arises of why some animals, apparently related, commenced chromosome fusion, when others did not. The Eday and Westray populations appear to have ceased chromosomal reduction at an early stage compared to the Italian populations $(2 n=22$ to $2 n=26)$. The Caithness mice on the other hand are continuing the process like those of southern Germany. If the capacity for centric fusions is itself a polymorphism then the combination of founder effects and heterozygosity reduction following isolation may account for the differing situations on the islands and in Caithness, among otherwise related animals. These populations therefore present us with material for investigating the process in action at both the population and molecular levels.

Acknowledgements. We thank Professor R. J. Berry and Dr Miriam Newton for collecting some of the mice, and Professor R. J. Berry for critical reading of the manuscript. We also thank Mr Peter Challinor for technical assistance, and Dr Sabine Adolph for stimulating discussion.

This work was supported by the M.R.C. (H.R.N.), the N.E.R.C. (P.C.B.) and the Royal Society (S.J.M.D.).

\section{REFERENCES}

ADOLPH, S. AND KLEIN, J. 1981. Robertsonian variation in Mus musculus from Central Europe, Spain and Scotland. J. Hered., 72, 219-221.

ADOLPH, S. AND KLEIN, J. 1982. Genetic variation of wild mouse populations in southern Germany. I. Cytogenetic study. Gen. Res. (in press).

BERRY, R. J. 1966. The origin of island mice. Mamm. Soc. Bull., 26, 8-9.

BERRY, R. J. AND PETERS, J. 1977. Heterogeneous heterozygosities in Mus musculus populations. Proc. R. Soc. Lond. B., 197, 485-503.

BRITTON-DAVIDIAN, J., BONHOMME, F., CROSET, H., CAPANNA, E. AND THALER, L. 1980. Variabilité génétique chez les populations des Souris (genre Mus L.) à nombre chromosomique réduit. C.R. Acad. Sc. Paris, 290, 195-198.

BROOKER, P. C. 1982 . Robertsonian translocations in Mus musculus from N. E. Scotland and Orkney. Heredity, 48, 305-309.

CAPANNA, E., CIVITELLI, M. V. AND CRISTALDI, M. 1977. Chromosomal rearrangement, reproductive isolation and speciation in mammals. The case of Mus musculus. Boll. Zool., 44, 213-246. 
CAPANNA E. AND CORTI, M. 1982. Mammalia (in press).

CATt ANACH, B. M. (1982). Private Communication. Mouse News Lett., 66, 62-63.

DAVIS, S. J. M. 1983. Morphometric variation of populations of house mice (Mus domesticus) in Britain and Faroe. J. Zool. Lond. (in press).

GROPP, A., TETTENBORN, U. AND VON LEHMANN, E. 1970. Chromosomenvariation vom Robertson'schen Typus bei der Tabakmus, $M$. poshiavinus, und ihren Hybriden mit der Laboratoriumsmaus. Cytogenet, 9, 9-23.

GROPP, A. AND WINKING, H. 1981. Robertsonian translocations: Cytology, meiosis, segregation patterns and biological consequences of heterozygosity. In Biology of the House Mouse, (ed. R. J. Berry). Academic Press (Lond).

HARRIS, H. AND HOPKINSON, D. A. 1976. Handbook of Enzyme Electrophoresis. NorthHolland Press. Amsterdam.

HUNT, G. W. AND SELANDER, R. K. 1973. Biochemical gentics of hybridisation in European house mice. Heredity, 31, 11-33.

NADEAU, J. H. AND EICHER, E. M. 1982. Conserved linkage of soluble aconitase and galactose -1- phosphate uridyl transferase in mouse and man: assignment of these genes to mouse chromosome-4. Cytogenet. Cell Genet. (in press).

NASH, H. R. AND VON DEIMLING, O. 1982. Kidney esterases of Mus musculus: further polymorphism of esterase 6, esterase-9, and a new esterase, esterase-20. Biochem. Genet., 20, 537-554.

NEWTON, M. F., NASH, H. R., PETERS, J. AND ANDREWS, S. J. 1982. Xylose dehydrogenase-1, a new gene on mouse chromosome-7. Biochem. Genet., 20, 733-745.

NICHOLS, E. A. AND RUDDLE, F. H. 1973. A review of enzyme polymorphism, linkage, and electrophoretic conditions for mouse and somatic cell hybrids in starch gels. J. Histochem. Cytochem., 21, 1066-1081.

NICHOLS, E. A. AND RUDDle, F. H. 1975. Polymorphism and Linkage of Glutathione Reductase in Mus musculus. Biochem. Genet., 13, 323-329.

OTTO, J. AND VON DEIMLING, O. 1981. Prt 4 and Prt 5: New constituents of a gene cluster in chromosome-7 coding for esteroproteases in the submandibular gland of the house mouse (Mus musculus). Biochem. Genet., 19, 431-444.

PETERS J. AND NASH, H. R. 1978. Esterases of Mus musculus: Substrate and inhibition characteristics, new isozymes, and homologies with man. Biochem. Genet., 16, 553-569.

SPIRITO, F., MODESTI, A., PERTICONE, P., CRISTALDI, M., FEDERICI, R. AND RIZZONI, M. 1980. Mechanisms of fixation and accumulation of centric fusions in natural populations of Mus musculus. I. Karylogical analysis of a hybrid zone between two populations in the central Appenines. Evolution, 34, 453-466.

THORPE, R. S., CORTI, M. AND CAPANNA, E. 1982. Morphometric divergence of Robertsonian populations/species of Mus: A multivariate analysis of size and shape. Experientia, 38, 920-923. 